\title{
Microplastic ingestion by Characidae in rural streams (Rio Grande do Sul, Brazil)
}

\author{
Leandro Ferrari ${ }^{1}$ \\ Luiz Ubiratan Hepp ${ }^{1,2 *}$ \\ ${ }^{1}$ Programa de Pós-graduação em Ecologia \\ Universidade Regional Integrada do Alto Uruguai e das Missões \\ Avenida Sete de Setembro, 1621, CEP 99.709-910, Erechim - RS, Brazil \\ ${ }^{2}$ Universidade Federal de Mato Grosso do Sul, Campus Três Lagoas \\ Avenida Ranulpho Marques Leal, 3484, Distrito Industrial, CEP 79.620-080, Três Lagoas - MS, Brazil \\ * Autor para correspondência \\ luizuhepp@gmail.com
}

Submetido em $21 / 05 / 2021$

Aceito para publicação em 05/08/2021

\section{Resumo}

Ingestão de microplásticos por Characidae em riachos rurais (Rio Grande do Sul, Brasil). Os microplásticas (MP) causam vários efeitos negativos sobre a biodiversidade, desde o ecossistema até os níveis individuais, podendo ser facilmente consumidos por pequenos invertebrados e peixes. O aumento da produção de plástico e a ausência de sistemas eficientes de gerenciamento desses resíduos facilitam sua presença em ambientes aquáticos. Neste estudo, avaliamos a presença de MP no conteúdo estomacal de quatro espécies de caracídeos em riachos rurais na porção superior da bacia hidrográfica do rio Uruguai (norte do Rio Grande do Sul). Dentre o total de organismos coletados $(\mathrm{n}=121)$, observou-se a presença de MP em $72 \%$ do conteúdo estomacal analisado. Bryconamericus iheringii apresentou a maior ocorrência de MP $(85,7 \%)$, seguida por Astyanax lacustris (69,4\%), Astyanax henseli (69,1\%) e Oligosarchus breviostris (66,7\%). Nossos resultados demonstram a alta ocorrência de MP em ambientes aquáticos de água doce, especialmente riachos rurais. Os resultados observados neste estudo reafirmam a importância da conservação dos riachos, a partir da manutenção da vegetação ripária como uma forma de reduzir a entrada de MP nesses ecossistemas.

Palavras-chave: Ambientes de água doce; Fibras plásticas; Partículas plásticas; Qualidade de água

\section{Abstract}

Microplastics (MP) have several negative effects on biodiversity, from the ecosystem to individual levels, and can be easily consumed by small invertebrates and fish. The increased production of plastic and absence of efficient management systems for these residues facilitate their presence in aquatic environments. In this study, we evaluated the presence of MP in the stomach contents of four species of Characidae in rural streams in the upper portion of the Uruguay River watershed (northern Rio Grande do Sul). Among the total of collected organisms $(\mathrm{n}=121)$, the presence of MP was observed in $72 \%$ of the analyzed stomach contents. Bryconamericus iheringii had the highest occurrence of MP (85.7\%), followed by Astyanax lacustris (69.4\%), Astyanax henseli (69.1\%) and Oligosarchus breviostris (66.7\%). Our results demonstrate the high occurrence of MP in freshwater aquatic environments, especially rural streams. The results observed in this study confirm the importance of conservation of streams, from the maintenance of riparian vegetation as a way to reduce the input of MP in these ecosystems.

Key words: Freshwater ecosystems; Plastic fibres; Plastic particles; Water quality 
The high consumpition of plastic has intensified in the recent decades, becoming an important pollutant for different types of environments (HITCHCOCK, 2020; SARIJAN et al., 2021). For a long time, the contamination of environments by microplastics (MPs) has been the subject of studies carried out in marine ecosystems (ERIKSEN et al., 2013; PENG et al., 2018). However, more recently this pollutant has been studied in continental aquatic ecosystems (McCORMICK et al., 2014; EERKES-MEDRANO et al., 2015; MANI; BURKHARDT-HOLM, 2020; WU et al., 2020).

In general, studies report the effects of plastics on environments at different scales (e.g. stretches to microbasins; STANTON et al., 2020). In these studies, most report the negative effects of MP particles on aquatic biota (COLE et al., 2013; MUELLER et al., 2020) and ecosystems (MA et al., 2020). The plastic material remains for long time in freshwater systems (BROWNE et al., 2011), thus remaining exposed to fauna (SANTOS et al., 2020). Different species of fish can ingest MP (SILVA-CAVALCANTI et al., 2017). Basically, the ingestion of MPs can occur directly in water or indirectly, when are associated with food resources ingested by organisms (DAVISON; ASCH, 2011)

The occurrence of MP is common in urban aquatic environments (HITCHCOCK, 2020). However, in rural streams information on the occurrence of this pollutant in aquatic environments is incipient (GARCIA et al., 2020). We evaluated the stomach content of species of Characidae as they are organisms with wide trophic plasticity (ESTEVES et al., 2021) and distribution in streams from several Brazilian biomes. Thus, in this study, we evaluated the occurrence of MP ingestion by Characidae in four rural streams in the upper portion of Uruguay River Hydrographic Basin (Rio Grande do Sul, Brazil).

The fish were collected in small order streams ( $<3$ rd order) located in rural area of municipalities of Barão de Cotegipe (Barbaquá Stream), Aratiba (Novo Stream) and Paulo Bento (Xaxim and Henrique Streams) (Figures 1 and 2), in the upper portion of Uruguay River hydrographic basin $\left(27^{\circ} 12^{\prime} 59^{\prime} \mathrm{S}\right.$ and $28^{\circ} 00^{\prime} 47^{\prime \prime} \mathrm{S} ; 51^{\circ} 49^{\prime} 34^{\prime \prime} \mathrm{W}$ and $52^{\circ} 48^{\prime} 12^{\prime \prime} \mathrm{W}$ ). The region has a subtropical temperate climate (ALVARES et al.,

FIGURE 1: Location of rural streams studied in the Uruguay River hydrographic basin (northern Rio Grande do Sul, Brazil).

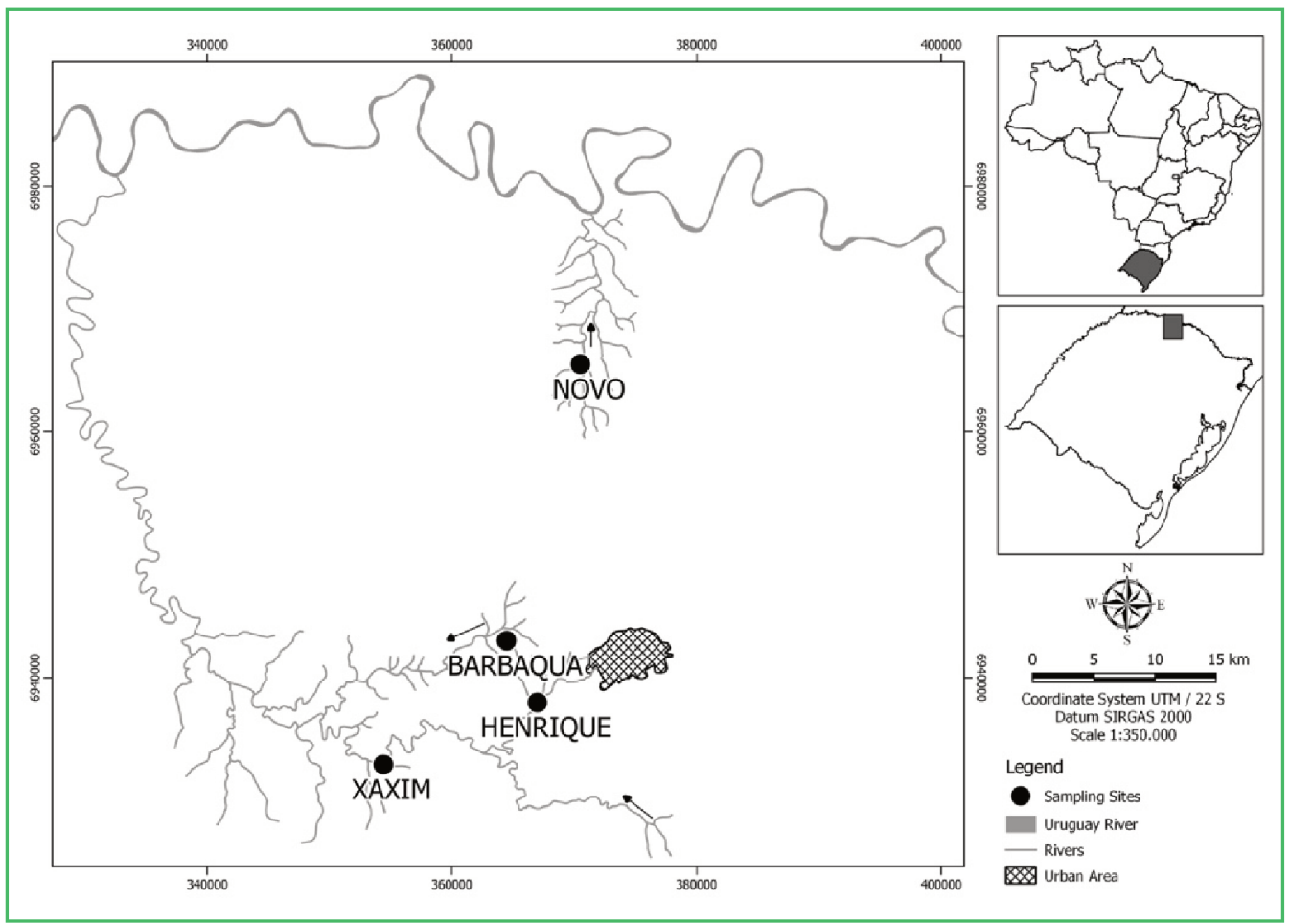


FIGURE 2: Overview of studied streams in the Uruguay River hydrographic basin (northern Rio Grande do Sul, Brazil). (A) Barbaquá Stream; (B) Novo Stream; (C) Xaxim Stream; (D) Henrique Stream.
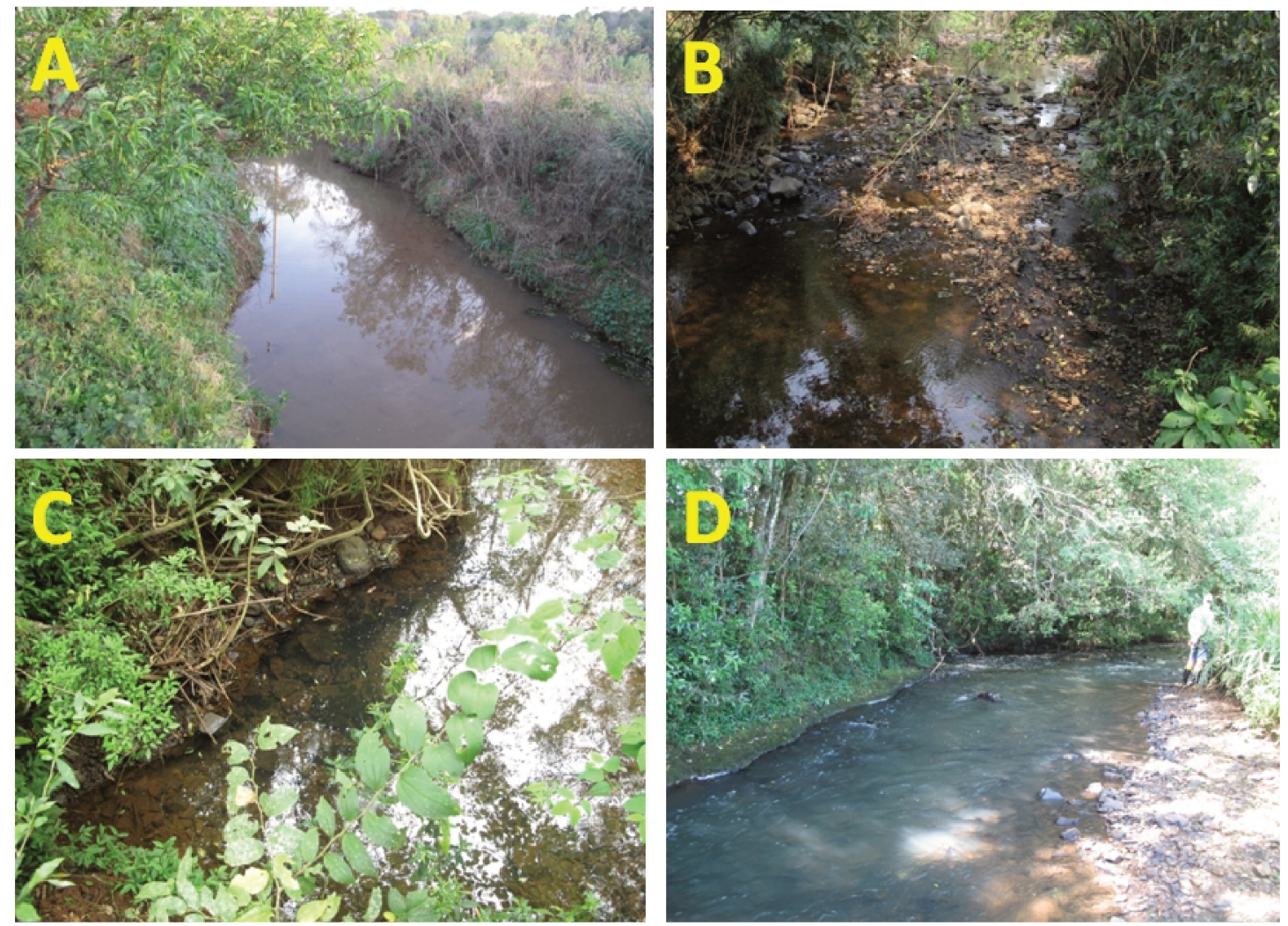

2013), is inserted in the Atlantic Forest biome, and the region landscape is mostly composed of agricultural uses (ROVANI et al., 2020). Limnological variables were quantified at sampling sites to characterize the studied streams. Using a Horiba ${ }^{\circledR}$ multiparameter analyzer it was observed that streams have well-oxygenated water $\left(>8 \mathrm{mg} . \mathrm{L}^{-1}\right)$, neutral to slightly acidic $\mathrm{pH}(6-7)$ and electrical conductivity $<0.1 \mathrm{mS} . \mathrm{cm}^{-1}$. Visually it was observed that sampled stretches have, basically composed of stones, with eventual banks of leaves and sand. The stream has riparian vegetation and agriculture (i.e. soy) in the adjacent areas (Table 1).

TABLE 1: Physical characteristics of studied streams in the Uruguay River hydrographic basin (northern Rio Grande do Sul, Brazil).

\begin{tabular}{|c|c|c|c|c|c|}
\hline Stream & Geographic coordinates & $\begin{array}{l}\text { Width } \\
\text { (m) }\end{array}$ & $\begin{array}{l}\text { Depth } \\
\text { (m) }\end{array}$ & Substrate & $\begin{array}{c}\text { Riparian } \\
\text { vegetation }\end{array}$ \\
\hline $\begin{array}{c}\text { Barbaquá } \\
\text { (Barão de Cotegipe) }\end{array}$ & $27^{\circ} 37^{\prime} 48^{\prime \prime} \mathrm{S} 52^{\circ} 22^{\prime} 25^{\prime \prime} \mathrm{W}$ & $<2$ & $<0.5$ & $\begin{array}{l}\text { Sand and } \\
\text { stone }\end{array}$ & $<10 \mathrm{~m}$ \\
\hline $\begin{array}{c}\text { Henrique } \\
\text { (Paulo Bento) }\end{array}$ & $27^{\circ} 40^{\prime} 32^{\prime \prime S} 52^{\circ} 20^{\prime} 55^{\prime \prime} \mathrm{W}$ & $<2.4$ & $<0.5$ & Stone & $>20 \mathrm{~m}$ \\
\hline $\begin{array}{c}\text { Novo } \\
\text { (Aratiba) }\end{array}$ & $27^{\circ} 25^{\prime} 39^{\prime \prime} \mathrm{S} 52^{\circ} 18^{\prime} 36^{\prime \prime} \mathrm{W}$ & $<5$ & $<0.8$ & Stone & $\sim 15 \mathrm{~m}$ \\
\hline $\begin{array}{c}\text { Xaxim } \\
\text { (Paulo Bento) }\end{array}$ & $27^{\circ} 43^{\prime} 11^{\prime \prime S} 52^{\circ} 28^{\prime} 37^{\prime \prime} \mathrm{W}$ & $<1.2$ & $<0.3$ & Stone & $\sim 15 \mathrm{~m}$ \\
\hline
\end{tabular}


We carried out two sampling collection between January and June 2020. For collections, we used a fishing net $(60 \times 40 \mathrm{~cm} ; 0.2 \mathrm{~cm}$ mesh), picaré-type net $(10 \times 2$ $\mathrm{m} ; 0.5 \mathrm{~cm}$ mesh) and/or with fishhook. The collected species were euthanized in Eugenol $\left(70 \mathrm{mg} \cdot \mathrm{L}^{-1}\right)$ and fixed in 10\% Formalin solution (LUCENA et al., 2013). After fixed, they were transferred to samples with $70 \%$ Ethanol solution until sorting and identification. The species have been identified at the taxonomic level are in agreement with Reis et al (2003) and Froese and Pauly (2021). The collections were authorized by the ICMBio (License 70751) and the Ethics Committee on the Use of Animals (CEUA/URI).

To analyze the presence of MP, we removed the stomach contents from specimens and digest the material in glass tubes with $10 \% \mathrm{KOH}$ solution in $\sim 60^{\circ} \mathrm{C} / 24$ to 48 h (SANTOS et al., 2020). The material resulting from digestion was analyzed using a stereomicroscope. We performed a qualitative assessment of the presence of MP in stomach contents, considering fibers, microfibers and other plastic fragments larger than $0.5 \mathrm{~mm}$. We applied a Chi-Square test to assess whether the proportions of stomach contents with the presence of MP were significantly different between the proportion of stomach without the presence of MP. As a way to control possible contamination of the samples, all the material was previously washed with ethanol and for each sample, the material used (i.g. petri dishes, tweezers) was changed.

During the sampling collection, a total of 121 individuals of Characidae were sampled, named: Astyanax henseli Melo \& Buckup 2006 (55 individuals), Astyanax lacustris Lütken 1875 (36 specimens), Bryconamericus iheringii Boulenger 1887 (21 individuals) and Oligosarchus breviostris Menezes 1987 ( 9 individuals). Among the four streams, we collected the largest number of individuals in the Barbaqua stream ( $53.7 \%$ of the total), followed by the Novo stream (26.4\%), Xaxim stream $(13.2 \%)$ and Henrique stream $(6.6 \%)$.

In general, $72 \%$ of the analyzed samples had some type of MP in their stomach contents (Figure 3). Among

FIGURE 3: Microplastics (circle) found in gut contents of (A) Astyanax henseli, (B) Astyanax lacustris, (C) Bryconamericus iheringii $\mathrm{e}$ (D) Oligosarchus breviostris in studied streams in the Unuguay River hydrographic basin (northen Rio Grande do Sul, Brazil). Black bars $=1 \mathrm{~mm}$.
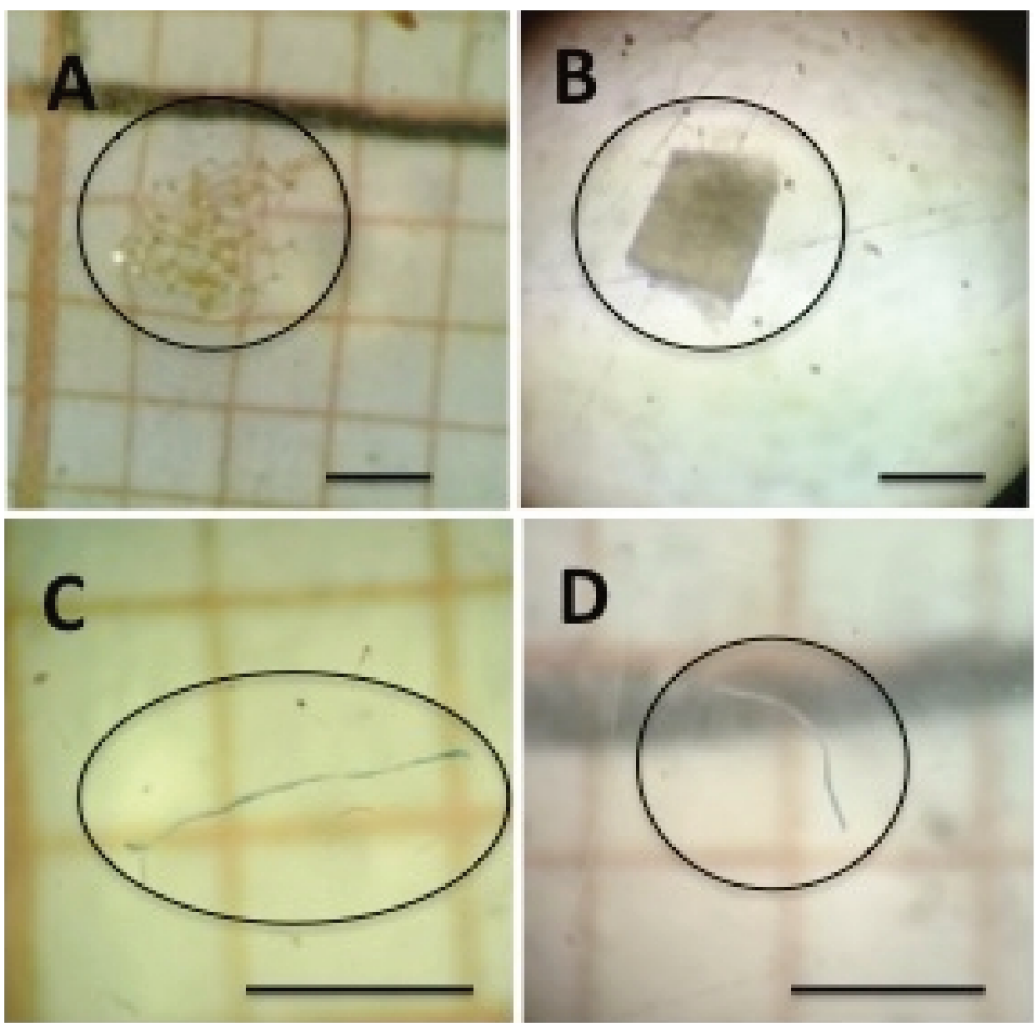
the four species collected, $B$. iheringii presented the highest occurrence of MP in stomach contents (85.7\%; $\left.\chi^{2}=8.0, \mathrm{p}=0.004\right)$, followed by A. lacustris (69.4\%; $\left.\chi^{2}=5.4, \mathrm{p}=0.019\right)$, A. henseli $\left(69.1 \% ; \chi^{2}=10.7, \mathrm{p}=\right.$ $0.001)$ and $O$. breviostris $\left(66.7 \% ; \chi^{2}=11.0, \mathrm{p}<0.001\right)$. We observed the incidence of MP in stomach content of four species in Henrique stream $\left(100 \% ; \chi^{2}=100.0\right.$, $\mathrm{p}=0.001)$ and Barbaqua stream $\left(100 \% ; \chi^{2}=31.1\right.$, $\mathrm{p}<0.001)$. The proportion of specimens with MP in stomach contents in Xaxim and Novo streams was $68.7 \%$ and $40.6 \%$, respectively.

Studies have reported a high incidence of MP from the stomach contents of different fish species in streams (AZEVEDO-SANTOS et al., 2019). However, knowledge of the expansion of this pollutant in the trophic chains of continental aquatic environments is still incipient (GARCIA et al., 2020). In general, the incidence of MP in stomach contents of fish species collected in this study was high. Comparing with similar studies, our results represent a percentage of individuals with MP in stomach content about $2 \times$ more than Santos et al. (2020).

The high incidence of MP in B. iheringii can be explained by its iliophage behavior, which consists of consumption of algae associated with the sediment (CASATTI et al., 2001; ORICOLLI; BENNEMANN, 2006). The MP can accumulate next to the sediment, or present negative buoyancy, which corroborate this result (SANTOS et al., 2020). In addition, although we have only studied species of the Characidae family, the presence of MP can be observed in different trophic guilds (AZEVEDO-SANTOS et al., 2019). This refers to the biomagnification of this pollutant, highlighting even more the results of this study, due to the high level of contamination observed in the studied organisms.

The streams studied are located in rural areas where there are agricultural activities (planting of soy, corn or wheat and cattle breeding). The urban perimeters close to these streams (approximately $500 \mathrm{~m}$ to 5,500 $\mathrm{m}$ ) are located downstream from the collection sites. Thus, the influence of urban activities on the supply of plastic waste in these streams is small. The region studied has significant agricultural activity $(\sim 80 \%$ of the total area; ROVANI et al., 2020). In this sense, the disposal of packaging for agricultural inputs associated with the inexistence of efficient solid waste management programs contributes to environmental contamination in the region.

In this study, we observed a high percentage of fish with MP in stomach contents. Although MP contamination is more evident in urban streams, our study demonstrated that this emergent pollutant is contaminating rural streams. In addition, considering that the streams studied are in headwaters of hydrographic basins, monitoring and control actions must be urgent. Finally, the presence of MP in stream fish also warns of mobility this pollutant through the aquatic food chain, which may contribute to the reduction of aquatic biodiversity and human health. An efficient strategy to contain MP pollution in small streams is (i) the conservation and recovery of riparian vegetation in these environments and (ii) implementation of solid waste management programs in rural areas.

\section{Acknowledgments}

We thank the support of our lab colleagues to assist in the field and laboratoty works. LF thanks to Coordenação de Aperfeiçoamento de Pessoal de Nível Superior (CAPES) for scholarship. LUH received financial support of the Conselho Nacional de Desenvolvimento Científico e Tecnológico (CNPq, Proc. \#421632/2016-0) and grants (\#305203/2017-7) and \#307212/2020-3).

\section{References}

ALVARES, C. A.; STAPE, J. L.; SENTELHAS, P. C.; GONÇALVES, J. L. M.; SPAROVEK, G. Köppen's climate classification map for Brazil. Meteorologische Zeitschrift, Viena, v. 22, p. 711-728, 2013.

AZEVEDO-SANTOS, V. M.; GONÇALVES, G. R. L.; MANOEL, P. S.; ANDRADE, M. C.; LIMA, F. P.; PELICICE, F. M. Plastic ingestion by fish: a global assessment. Environmental Pollution, Amherst, v. 255, p. 112994, 2019.

BROWNE, M. A.; CRUMP, P.; NIVEN, S. J.; TEUTEN, E.; TONKIN, A.; GALLOWAY, T.; THOMPSON, R. Accumulation of microplastic on shorelines woldwide: sources and sinks. Environmental Science \& Technology, Washington, v. 45, p. 9175-9179, 2011. 
CASATTI, L.; LANGEANI, F.; RICARDO, M. C. Peixes de riacho do Parque Estadual Morro do Diabo, bacia do alto rio Paraná, SP. Biota Neotropica, Campinas, v. 1, p. 1-15, 2001.

COLE, M.; LINDEQUE, P.; FILEMAN, E.; HALSBAND, C.; GOODHEAD, R.; MOGER, J.; GALLOWAY, T. S. Microplastic ingestion by zooplankton. Environmental Science \& Technology, Washington, v. 47, p. 6646-6655, 2013.

DAVISON, P.; ASCH, R. G. Plastic ingestion by mesopelagic fishes in the North Pacific Subtropical Gyre. Marine Ecology Progress Series, Luhe, v. 432, p. 173-180, 2011.

EERKES-MEDRANO, D.; THOMPSON, R. C.; ALDRIDGE, D. C. Microplastic in freshwater systems: a review of the emerging threats, identification of knowledge gaps and prioritization of research needs. Water Research, London, v. 75, p. 63-82, 2015.

ERIKSEN, M.; MASON, S.; WILSON, S.; BOX, C.; ZELLERS, A.; EDWARDS, W.; AMATO, S. Microplastic pollution in the surface waters of the Laurentian Great Lakes. Marine Pollution Bulletin, Amsterdam, v. 77, p. 177-182, 2013.

ESTEVES, K. E.; ARANHA, J. M. R.; ALBRECHT, M. P. Ecologia trófica de peixes de riacho: uma releitura 20 anos depois. Oecologia Australis, Rio de Janeiro, v. 25, p. 266-282, 2021.

FROESE, R.; PAULY, D. FishBase. World Wide Web electronic publication. Available in $<$ www.fishbase.org $>$.

GARCIA, T. D.; CARDOZO, A. L. P.; QUIRINO, B. A.; YOFUKUJI, K. Y.; GANASSIN, M. J. M.; SANTOS, N. C. L.; FUGI, R. Ingestions of microplastic by fich of different feeding habitats in urbanized a non-urbanized stream in Souther Brazil. Water, Air \& Soil Pollution, Dordrecht, v. 231, p. 434, 2020.

HITCHCOCK, J. N. Storm events as key moments of microplastic contamination in aquatic ecosystems. Science of the Total Environment, Amsterdam, v. 734, p. 139436, 2020.

LUCENA, C. A. S.; CALEGARI, B. B.; PEREIRA, E. H. L.; DALLEGRAVE, E. O uso de óleo de cravo na eutanásia de peixes. Boletim Sociedade Brasileira de Ictiologia, São Carlos, v. 105, p. 20-24, 2013.

MA, H.; PU, S.; LIU, S.; BAI, Y.; MANDAL, S.; XING, B. Microplastics in aquatic environments: toxicity to trigger ecological consequences. Environmental Pollution, Amherst, v. 261, p. $114089,2020$.

MANI, T.; BURKHARDT-HOLM, P. Seasonal microplastics variation in nival and pluvial stretches of the Rhine River - From the Swiss catchment towards the North Sea. The Science of the Total Environment, Barcelona, v. 707, p. 135579, 2020.

McCORMICK, A.; HOELLEIN, T. J.; MASON, S. A.; SCHLUEP, J.; KELLY, J. J. Microplastic is an abundant and distinct microbial habitat in an urban river. Environmental Science \& Technology, Washington, v. 48, p. 1863-1871, 2014.
MUELLER, M-T.; FUESER, H.; TRAC, L. N.; MAYER, P.; TRAUNSPURGER, W.; HÖSS, S. Surface-related toxicity of polystyrene beads to nematodes and the role of food availability. Environmental Science \& Technology, Washington, v. 54, p. 1790-1798, 2020.

ORICOLLI, M. C. G.; BENNEMANN, S. T. Diet of Bryconamericus iheringii (Ostariophysi: Characidae) from streams of Tibagi river basin, Parana State. Acta Scientiarum Biological Sciences, Maringá, v. 28, p. 59-63, 2006.

PENG, X.; CHEN, M.; CHEN, S.; DASGUPTA, S.; XU, H.; TA, K.; BAI, S. Microplastics contaminate the deepest part of the world's ocean. Geochemical Perspectives Letters, Aubiere, v. 9, p. 1-5, 2018.

REIS, R. E.; KULLANDER, S. O. C.; FERRARIS JR., J. Check list of the freshwater fishes of South and Central America. Porto Alegre: Edipucrs, 2003. 729 p.

ROVANI, I. L.; DECIAN, V. S.; ZANIN, E. M.; BRANDALISE, M.; QUADROS, F. R.; HEPP, L. U. Socioeconomic changes and land cover of the Northern Region of Rio Grande do Sul, Brazil. Floresta e Ambiente, Seropédica, v. 27, p. e20180258, 2020.

SANTOS, T.; BASTIAN, R.; FELDEN, J.; RAUBER, A. M.; REYNALTE-TATAJE, D. A.; DE MELLO, F. T. First record of microplastics in two freshwater fish species Iheringhthys labrosus and Astyanax lacustris) from the middle section of the Uruguay River, Brazil. Acta Limnologica Brasiliensia, Botucatu, v. 32, p. e26, 2020.

SARIJAN, S.; AZMAN, S.; SAID, M. I. M.; JAMAL, M. H. Microplastics in freshwater ecosystems: a recent review of occurrence, analysis, potential impacts, and research needs. Environmental Science and Pollution Research, Talance, v. 28, p. 1341-1356, 2021.

SILVA-CAVALCANTI, J. S.; SILVA, J. D. B.; FRANÇA, E. J.; ARAÚJO, M. C. B.; GUSMÃO, F. Microplastics ingestion by a common tropical freshwater fishing resource. Environmental Pollution, Amherst, v. 221, p. 218-226, 2017.

STANTON, T.; JOHNSON, M.; NATHANAIL, P.; MACNAUGHTAN, W.; GOMES, R. L. Freshwater microplastic concentrations vary through both space and time. Environmental Pollution, Amherst, v. 263, p. 114481, 2020.

WU, C.; ZHANG, K.; XIONG, X. Microplastic pollution in inland waters focusing on Asia. In: M. Wagner and S. Lambert eds. Freshwater microplastics: emerging environmental contaminants? Genève: Springer Open, 2020. p. 101-124. 